УДК $341.1 / 8$

DOI https:/ / doi.org/10.32837/yuv.v0i1.1654

А. Гандзюра,

здобувач кафедри порівняльного ї європейського права

Інституту міжнародних відносин

Київського національного університету імені Тараса Шевченка

\title{
СТРАТЕГIЧНЕ ПАРТНЕРСТВО ЯК ІНСТРУМЕНТ РЕАЛІЗАЦІї МІЖНАРОДНИХ ДВОСТОРОННІХ ВІДНОСИН
}

Сучасні зовнішньополітичні відносини країн характеризуються значним динамізмом і підвищенням взаємозалежності держав, як наслідок, активізацією двосторонніх міжнародних відносин. Актуальною є тенденція до проголошення стратегічного партнерства між акторами на міжнародній арені. Це передусім зумовлено тим, що декларація відносин стратегічного партнерства демонструє винятковість або надзвичайну важливість таких відносин для країн-партнерів. Однак поняття стратегічного партнерства, фундаментальні основи та принципи його практичного застосування досі викликають багато питань, що зумовлює актуальність розроблення розвідки.

Метою статті $€$ визначення умов трансформації міжнародного двостороннього співробітництва в стратегічне партнерство та основоположних принципів його практичного втілення.

Проблематиці стратегічного партнерства в українській науці присвячено роботи В. Жовкви, Е. Лисицина, Г. Перепелиці, С. Толстова, В. Шамраєвої, Л. Чекаленко, О. Разумкова, А. Козирєва, Б. Тарасюка, І. Погорської, Є. Макаренко, Н. Ржевської та ін. Значна увага стратегічному партнерству як феномену приділяється в працях таких західних дослідників, як Б. Лідделл Харт, В. Муррей та М. Гріслі, Дж.М. Колінз.

Дослідження концепту стратегічного партнерства варто розпочати через базисне розуміння національних інтересів. Поняття національних інтересів досить широке, вони визначаються в різних сферах: економічній, політичній, соціальній тощо - i 3 наукового погляду стали предметом вивчення багатьох дослідників [1].

Для задоволення своїх національних інтересів найбільш перспективною формою взаємодії держави є співпраця, яка реалізується через участь у різних міжнародних структурах і різнорівневі договори про дружбу і співробітництво. Співпраця як вид міжнародної взаємодії використовується в усіх сферах міжнародної діяльності, а синонімом цього поняття $€$ термін «партнерство». Варто зазначити, що «це поняття остаточно сформувалося після Другої світової війни як результат подолання наслідків тоталітаризму в країнах Західної Європи. Передусім партнерство трактувалося як політика компромісу та ідеологічна основа економічної політики соціал-демократичних урядів. «Холодна війна», що почалася, створювала морально-політичне тло, яке змушувало шукати вихід із важкої соціальної конфронтації. I лише з часом на зміну конфронтації прийшло змагання, а потім і партнерство сторін, що стало необхідним компонентом соціального миру та економічного процвітання» [2, с. 13-16].

Одним із різновидів співпраці є стратегічне партнерство. Поняття «стратегічне партнерство» вже давно посіло вагоме місце в практичних процесах міжнародних відносин, будучи комп- 
лексним і багатоаспектним [3]. Цей інструмент реалізації зовнішньої політики передбачає найбільш масштабний і вигідний для всіх сторін спосіб взаємодії в різноманітних сферах і галузях, відповідає геостратегічним інтересам задіяних суб’єктів. Стратегічне партнерство має винятковий характер порівняно з іншими міжнародними відносинами та грунтується саме на забезпеченні національних інтересів [1].

Використовуючи стратегічне партнерство, держава так узгоджує свої дії на міжнародній арені з іншими державами. Саме взаємодія у використанні цього інструмента та збіг стратегічних національних інтересів двох чи більше держав у декількох сферах призводять до виникнення між ними особливого виду міждержавного співробітництва. $\mathrm{У}$ сучасній міжнародній системі стратегічне партнерство набуває дедалі важливішого значення й впливу порівняно 3 іншими видами співробітництва, які засновані на об'єднанні проти спільного ворога або базуються лише на одній галузі співробітництва [4].

Більшість вітчизняних дослідників сходяться в баченні, що «основною умовою для проголошення міждержавних відносин на принципах стратегічного партнерства $€$ повний або частковий збіг стратегічних цілей країн-партнерів». В основі іншого підходу до проблем визначення стратегічного партнерства лежить аналіз і розуміння ключових складників - понять «стратегія» Й «Партнерство». При цьому «принциповим $€$ визначення зовнішньополітичної стратегії держави, тоді як стратегічне партнерство розглядається як засіб їі реалізації» [5, с. 68].

Отже, можемо говорити про те, що під стратегічним партнерством розуміється такий рівень співробітництва між державами, який передбачає здійснення ними спільних дій для задоволення своїх ключових національних інтересів. Важливими принципами такого партнерства є довготривалість, максимальна ефективність і взаємовигідність. Безумовно, воно виключає допустимість будь-яких несправедливих або дискримінаційних дій однієї держави щодо іншої. Розуміється, що незалежно від зміни керівництва країн-партнерів спільно ухвалені рішення підлягають послідовному виконанню. Зазначається, що «якщо сьогоденні інтереси однієї 3 держав суперечать духу стратегічного співробітництва між ними, то не виключається можливість поступитися такими інтересами на користь партнера (задля досягнення компромісу). У будь-якому разі подібні дії мусять бути продиктовані умовами, що склалися, і спільним курсом, якого держави дотримуються на міжнародній арені» [3, с. 164].

Розглядаючи стратегічне партнерство як довгострокове і взаємовигідне співробітництво рівноправних суб'єктів міжнародних відносин для вирішення важливих завдань, необхідно брати до уваги такі умови: наявність ключових цілей, досягнення яких вимагає взаємної координації зусиль сторін у довгостроковій перспективі; спільне й однакове розуміння цілей і засад розвитку стратегічного партнерства суб'єктами; актуальна договірно-правова база партнерства, яка чітко закріплює зміст цього співробітництва й механізми його фактичної реалізації; усталений інституційний механізм, який забезпечує реалізацію стратегічного партнерства; перевага спільних цілей над розбіжностями тощо, а перешкодами на шляху до стратегічного партнерства можуть стати різниця підходів до будови політичної системи та негативні історичні стереотипи сприйняття партнера [6].

Серед бажаних умов сприятливого стратегічного партнерства вбачаються «спільний кордон, збіг засадничих рис розвитку, доповнюваність економік обох країн, перспектива розв'язання ресурсних (стратегічних) проблем краіни, розширення ринку збуту товарів тощо» $[7$, с. 10$]$.

Формат стратегічного партнерства побудований як послідовна система взаємодії держав, спрямована на реалізацію спільних цілей, стратегічних 


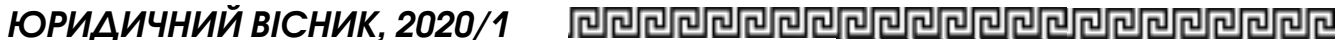

завдань та інтересів. На відміну від союзницьких відносин, цей вид співробітництва не передбачає жорстокої системи зобов'язань різнопланового характеру сторін (політичного, економічного, гуманітарного або безпекового). Водночас «відносини стратегічного партнерства встановлюються між сторонами, що мають стратегічне значення одна для одної, і звідси спроможні завдяки партнерським відносинам впливати на реалізацію інтересів країн як у національному, так і в більш широкому міжнародному контексті» [8, с. 58,59$]$.

Проаналізувавши втілення відносин стратегічного партнерства держав на практиці, можемо виділити такі основні його моделі: фактичне, декларативне, прагматичне, представницьке та асиметричне стратегічне партнерство. Звичайно, зазначені моделі є схематичними й можуть використовуватися лише для загального й цілісного розуміння цього поняття.

Під час фактичного стратегічного партнерства після встановлення відносин держави активно розвивають його на всіх рівнях протягом певного періоду часу, намагаючись спільно досягнути цілей і задоволення національних інтересів, визнаючи зобов'язання один перед одним, сторони готові йти на взаємні поступки та компроміс. Якщо стратегічне партнерство має характер декларативного, держави укладають договір про стратегічне партнерство, але його положення не реалізовуються в зазначених напрямах або проводяться лише формальні зустрічі представників сторін, які в подальшому не мають практичного наповнення. Прагматичне стратегічне партнерство держав передбачає встановлення відносин виключно з метою ї розвитку в окремій галузі, а представницьке - установлення партнерства в окремих регіонах чи організаціях з метою реалізації власних інтересів локально в цих регіонах і просування своїх інтересів і проектів. Для асиметричного стратегічного партнерства характерним є встановлення відносин партнерства за домінантності однієї зі сторін.

Кожне практичне стратегічне партнерство неможливо однозначно зарахувати до тієї чи іншої моделі. Для одного партнерства можуть використовуватися декілька моделей водночас або чергуватися, змінюючи одна одну. Справжньому стратегічному партнерству притаманна низка принципів, таких як «високий ступінь співробітництва й довіри, прозорість відносин, що означає широку взаємодію в міжнародних справах і відсутність спрямованості супроти третіх країн, широта партнерства не тільки в економічній сфері, а й у політичній сфері, тісна координація зовнішньополітичних дій на всіх ключових напрямах світової та двосторонньої співпраці, обов'язкова довготривалість відносин, оскільки це $€$ запорукою політичних і військових гарантій. Водночас стратегічні партнери мають ураховувати низку обставин, пов'язаних із геополітичними й геоекономічними інтересами інших країн-партнерів» [9]. При цьому для плідної фактичної реалізації партнерства додатком до базового міждержавного договору має стати довгострокова програма стратегічного співробітництва 3 основних напрямів. Отже, стратегічне партнерство можливе виключно за умов жорсткої реалізації взятих на себе зобов' язань [9].

Щодо реального стану двосторонніх відносин України іншими державами не завжди цілком однозначно ствердно можна характеризувати досягнутий рівень відносин як стратегічний, навіть 3 огляду на його відповідність зазначеним формальним критеріям. Часто для справжньої «стратегічності» бракує об'єктивних підстав, передумов, мотивації однієї чи обох сторін, а також реального наповнення відносин фактичними здобутками. У таких «стратегічних відносинах» переважає декларативний складник, риторика, а сподівання, що в майбутньому справді буде досягнутий такий високий рівень відносин, не завжди обгрунтовані [5].

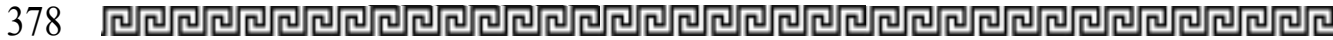


Стратегічне партнерство для свого ефективного практичного втілення потребує чіткої визначеності щодо головних напрямів взаємодії акторів, засобів досягнення цілей, етапів реалізації співробітництва, запобігання чинникам, що можуть стати перепоною для здійснення запланованого. Оскільки стратегічною метою довгострокового співробітництва $€$ двостороння вигода, обидві сторони зацікавлені у взаємному використанні ресурсів задля спільних цілей, про що повідомляють відповідні документи. Проте, як свідчить міжнародно-правова практика, «загалом сторони не поспішають заявляти про юридичну формалізацію більш тісних стосунків, що може призвести до злиття чи поглинання, як це не раз траплялося у світовій історії. Завжди існує певний ризик, що в рамках стратегічного партнерства більш слабка держава (компанія) намагається співробітничати 3 більш потужною і впливовою державою (компанією), а політичні лідери не завжди ретельно працюють над змістом намірів співробітництва у функціональному й часовому вимірі» [10].

$\mathrm{V}$ контексті сучасних геополітичних змін у міжнародній системі та розвитку комплексу міждержавних відносин у ній характер і зміст інтеграційних процесів у світі потенційно вибудовуються як відносини стратегічного партнерства й союзництва. Особливого значення інтеграційні процеси набувають на глобальному рівні через перерозподіл світових сил і міжнародне протистояння, що зростає. Спостерігається міцна наявність інтеграції в структурі міжнародних відносин суб'єктів, у ролі яких виступають як окремі суверенні держави, так і різні об'єднання, що утворюють групи й блоки країн. При цьому складається парадоксальна ситуація, коли політичні суб'єкти інтеграції, з одного боку, заявляють про розбудову та посилення відносин взаємовигідного співробітництва між собою, а з іншого - інтеграція в їхніх практичних діях лише потенційно може набути значення відносин стратегічного партнерства й союзництва [11].

Стратегічне партнерство $€$ довготривалим явищем i потребує окреслення дій на перспективу, хоча деякі країни надають перевагу його короткочасності. Зокрема, важливим є визначення його місця в структурі зовнішніх зв'язків $з$ урахуванням національних, стратегічних і поточних інтересів, які можуть бути реалізовані через наявні зв'язки. Вагому роль відіграє виявлення можливостей послаблення або подолання впливу на них негативних чинників і посилення тих чинників, що стимулюють розширення цих зв'язків, а також визначення контурів раціональної структури співробітництва за його видами та напрямами з виокремленням поточних і довгострокових пріоритетів [12].

Варто додати, що двосторонні відносини звично сприймаються як база для вирішення різних питань, але така логіка має бути переосмислена, принаймні частково. Стратегічне партнерство автоматично не призводить до співпраці в усіх галузях і його однакової ефективності в кожному випадку. Крім того, стратегічні партнерства фокусуються на двосторонніх відносинах, але нерідко досягнення анонсованих цілей залежить від участі третіх країн. Важливим є розуміння, що стратегічне партнерство буде дійсно стратегічним лише тоді, коли воно виходить за межі економічного блоку відносин. У фокусі уваги має бути ефективне вирішення політичних питань і питань безпеки на системній і структурованій основі, включаючи спільні зусилля в протистоянні геополітичним кризам i звичайним міжнаціональним загрозам. Щодо перспектив стратегічного партнерства, то головним завданням $€$ розроблення механізму, здатного, з одного боку, формувати довгострокові цілі співробітництва, а з іншого запобігати появі проблем на шляху розвитку таких відносин [13].

Важливою концептуальною основою, яка є структурою для подальшої 


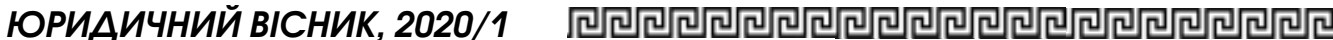

реалізації планів, відкриваючи простір для нових досягнень із більш високою динамікою відносин і суттєвими результатами, є документальне оформлення стратегічного партнерства. Воно призводить до посилення структурної взаємодоповнюваності й кореляції між двома країнами [14, с. 83].

Міжнародно-правове втілення стратегічного співробітництва частіше за все представлене не як компоненти загального політичного процесу, а як окремі несистематизовані прояви у формі меморандумів, декларацій і хартій, загальних документів, які можна зарахувати до актів м'якого права, що не визначають конкретні сфери співробітництва та не містять детальних планів щодо їх реалізації [10].

Під час усебічного розгляду концепту стратегічного партнерства важливим убачається розуміння часу або моменту його укладання. Для ефективного фактичного втілення стратегічного співробітництва й досягнення спільних цілей «важливо, аби такий момент збігався з кумуляцією багаторічного безперервного зростання в динаміці взаємовідносин. Саме часовий компонент i своєчасне рішення про укладання договору про стратегічне партнерство $€$ таким, що може серйозно вплинути на динаміку зміцнення відносин i ix подальше осмислення» [14, с. 83].

Отже, термін «стратегічне партнерство» часто фігурує в риториці політиків багатьох держав. Він широко використовується політиками тоді, коли потрібно підкреслити особливу значущість відносин або моменту, проте в кожному конкретному випадку під цим терміном політики мають на увазі різний ступінь розроблення відносин і перспектив [11]. Стратегічне партнерство посідає дедалі важливіше місце порівняно $з$ іншими видами співробітництва, які засновані на об'єднанні проти спільної загрози або орієнтовані лише на окрему конкретну сферу співробітництва [10].

Інструмент стратегічного партнерства дедалі ширше використовується провідними країнами та інтеграційними об'єднаннями, виступаючи одним із важливих інструментів зовнішньої політики, він дає змогу підвищити результативність дій на міжнародній арені. Довгострокове, випробуване часом партнерство стає гнучким механізмом взаємодії країн, які об'єднує мета - вирішити стратегічні завдання для реалізації власних національних інтересів і підвищення загальної стабільності у світі. Поглиблення глобальної та регіональної конкуренції, загострення боротьби за ринки збуту й природні ресурси на тлі наростання негативних тенденцій у міжнародній системі випробують міцність стратегічних відносин. Додаткові виклики для консолідації країн-партнерів і водночас можливості для появи нових конфігурацій міжнародного партнерства зумовлюють перерозподіл міжнародного балансу сил і стрімкий розвиток нових глобальних взаємозв'язків [15].

Разом із тим партнери повинні враховувати низку обставин, пов'язаних із геополітичними та геоекономічними інтересами інших країн-партнерів. Серед складників, які визначають сутність стратегічного партнерства, виділяються «високий ступінь співробітництва й довіри; прозорість відносин, що означає широку взаємодію в міжнародних справах і неспрямованість проти третіх країн; широта партнерства не тільки в економічній сфері, а й у політичній (наприклад, зміцнення регіональної безпеки тощо); тісна координація зовнішньополітичних кроків у всіх ключових напрямах світових і двосторонніх проблем розвитку; характер відносин із країною-партнером як самодостатня величина, що не піддається кон'юнктурним впливам; обов'язкова довготривалість відносин, оскільки вона містить комплекс політичних і військових гарантій» [7]. Варто також мати на увазі той факт, що сучасний світ змінюється дуже швидко, з'являються нові сфери й напрями міждержавної взаємодії, які доповнюють зміст стратегічного партнерства. Важливим 
питанням $є$ утримання фокусу уваги на практичному втіленні та засобах реалізації стратегічного партнерства. Реалізація політики і стратегічного партнерства як однієї з ї форм завжди $€$ комплексним процесом, що, з одного боку, вимагає чіткої програми дій, а 3 іншого - здатності реагувати на мінливі обставини, згідно з основними положеннями програми. Крім того, доцільною є наявність інституційної структури, яка б була досить гнучкою, щоб уможливити досягнення результатів $[14$, с. 83$]$.

У статті розкривається зміст i cутність поняття стратегічного партнерства, витоки й засади формування иієї форми міннародно-правової взаємодії. Динамізм сучасних зовнішньополітичних відносин сприяе активному проголошенню стратегічного партнерства між державами, що спрямоване на демонстрацію винятковості або надзвичайної важливості таких відносин для країн-партнерів. Серед основоположних принципів такої двосторонньої взаємодії важливими визначають існування принципово важливих иілей, досягнення яких можливе лише за серйозної координації зусиль сторін у довгостроковій перспективі, $i$ єдине розуміння цілей $i$ приниипів розвитку стратегічного партнерства сторонами. Украй важливою є наявність актуальної правової бази партнерства, де закріплені зміст співробітництва та механізми його реалізаціі, а також існування усталених інституційних механізмів, за допомогою яких стратегічне партнерство реалізується. Теоретико-методологічні засади стратегічного партнерства залишаються маловивченими й потребують детального аналізу наявного досвіду та розроблення керівних універсальних приниипів для забезпечення ефективного практичного втілення двосторонніх відносин стратегічного значення. Загалом стратегічне партнерство в міжнародних відносинах розуміється як довгострокове взаємовигідне співробітництво рівноправних суб'єктів міннародних відносин для вирішення найважливіших завдань. Однак на практиці з еволюцією окремих відносин між акторами на міжнародній арені стає очевидною переважна асиметричність у балансі сил між декларованими стратегічними партнерами, відсутність юридичної формалізації взаємних зобов'язань, загальна риторичність наповнення двосторонніх угод. У cmammi nорушено аспект проблеми практичного наповнення стратегічного співробітництва з огляду на динамізм y міждержавних відносинах $i$ певні чинники, які варто брати до розгляду, звертаючись до формату стратегічного партнерства між країнамu.

Ключові слова: стратегічне співробітництво, партнерство, моделі міжнародних відносин, двостороннє співробітництво.

Gandziura A. Strategic partnership implementation as an instrument of international bilateral relations

The article reveals the content and essence of strategic partnership concept, origins and formation principles of international legal cooperation. The dynamism of modern foreign policy relations promotes active proclamation of strategic partnership between the states, aimed at demonstrating the exclusiveness or the extreme importance of such relations for partner countries. Among the fundamental principles of such bilateral cooperation one can name the existence of fundamentally important goals, which can only be achieved if there is a serious long term coordination of the parties' efforts and a common understanding of the goals and principles of the strategic partnership development by the parties. It is extremely important to have an up-to-date legal framework for partnership, which sets out the content 
of cooperation and mechanisms for its implementation, as well as the existence of established institutional mechanisms through which strategic partnership is implemented. The theoretical and methodological foundations of strategic partnership remain poorly investigated and require a thorough analysis of available experience and the development of universal guidelines to ensure the effective practical implementation of bilateral relations of strategic importance. In general, strategic partnership in international relations is understood as the longterm mutually beneficial cooperation of equal subjects of international relations in order to solve the most important tasks. However, in practice, with the evolution of particular relations between actors on the international arena, the asymmetry in the balance of power between the declared strategic partners, the lack of legal formalization of mutual obligations, the general rhetoric of the bilateral agreements are evident. The article deals with the problem of practical filling of strategic cooperation in view of the interstate relations dynamism and certain factors that should be considered when referring to the format of strategic partnership between countries.

Key words: strategic cooperation, partnerships, models of international relations, bilateral cooperation.

\section{Література}

1. Горбачова Н.С. Можливість використання стратегічного партнерства $з$ метою впливу на національні економічні iнmepecu. URL: https://ir.kneu.edu.ua/ bitstream / handle /2010/4443/Gorbachova. pdf? sequence $=1$.

2. Набиулинна М.Н. Формирование и развитие социального партнерства в сфере образования. Москва: РГБ, 2003. 436 с.

3. Шамраєва B.M. Стратегічне партнерство як інструмент зовнішньої політики держави (історіографія проблеми). Державне будівниитво. 2012. № 1. С. 154-164.

4. Солянова М.В. Американские концепции полицентричного мира. Россия и Америка в XXI веке. 2011. № 1. URL: http: / / www.rusus.ru / ?act=read\&id $=232$.

5. Лоссовський I.Є. Cтратегічне партнерство України з країнами Європи: формальне декларування та реальні здобутки. URL: http: / / elibrary.ivinas.gov.ua/ 3811/1/Zbirnyk-032015.pdf.

6. Новиков И.А. Отношения России u Европейского Союза: проблемь и факторы развития стратегического партнерства : автореф. дисс. ... канд. полит. наук : 23.00.04 «Политические проблемы международных отношений глобального и регионального развития». Санкт-Петербург, 2011. URL: http://www.dissercat.com/content / otnosheniya-rossii-i-evropeiskogo-soyuzaproblemy-i-faktory-razvitiyastrategicheskogopartn.

7. Чекаленко Л.Д. Стратегічне партнерство: плюси i мінуси. URL: http:// elibrary.ivinas.gov.ua/3811/1/Zbirnyk032015.pdf.

8. Дудко І.Д. Феномен стратегічного партнерства США $і$ України: ретроспектива i сучасність. URL: http:// elibrary.ivinas.gov.ua/3811/1/Zbirnyk032015.pdf.

9. Гнип O. Cmратегічне партнерство mа його моделі у міжнародних відносинах. URL: http:/ / ena.lp.edu.ua:8080/handle/ $n t b / 19312$.

10. Ржевська Н.Ф. Стратегічні прогнози щодо перспектив стратегічного партнерства для України. URL: http:// journals.iir.kiev.ua/index.php/apmv/ article / view / $3647 / 3315$.

11. Фесенко М. Глобальне стратегічне партнерство провідних акторів: теоретико-методологічний вимір. URL: http:/ / journals.iir.kiev.ua/index.php/knu/article/ view / 2797 / 2507.

12. Чекаленко Л.Д. Зовнішня політика України : підручник / занаук. ред. ректора Дипломатичної академії України при МЗС України М.А. Кулініча ; відп. ред. перший проректор ДАУ при МЗС України В.Г. Ціватий. Київ : LAT\&K, 2015. 477 c.

13. Резнікова Н.В. Економічний потенціал Всеохоплюючого стратегічного партнерства ЄC та КНР. Розвиток новітніх форм міжнародної економічної інтеграції на початку ХХІ століття : монографія / О.І.Шнирков,А.С. Філіпенко,Р.О.Заблоцька, 3.О Луц̧ишин та ін. ; за ред. О.І. Шниркова. Київ : ВПЦ «Київський університет», 2016. URL: http://194.44.12.92:8080/ jspui/handle/123456789/3345. 


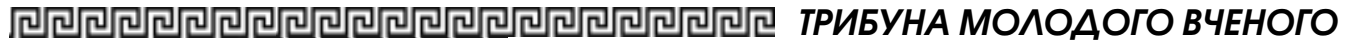

14. Мальшина К.В., Язбеи М. Досвід словенсько-турецького стратегічного партнерства для України. URL: http: / / elibrary. ivinas.gov.ua/3811/1/Zbirnyk-032015.pdf.

15. Парахонський Б., Яворська Г. Стратегічне партнерство України: аналітична записка. URL: http://www.niss.gov.ua/ articles $/ 600 /$.

16. Пашков М. Реалии и перспективы стратегического партнерства. URL: http: / / razumkov.org.ua/ukr / article.php? news_id=104.

17. Студінська Г.Я., Студінський B.A. Стратегічне партнерство України та ЄC. Формування ринкових відносин в Українi. 2018. № 7-8. C. 22-36. URL: http:// nbuv.gov.ua/UJRN/frvu_2018_7-8_5.

18. Жовква I.I. Моделі стратегічного партнерства. Актуальні проблеми міжна- родних відносин : збірник наукових пращь. Київ : Київський наи. ун-т ім. Т. Шевченка. Iн-т міжнар. відносин, 2003. № 41. 4. II. C. 32-38.

19. Жовква I.I. Cтратегічне партнерство у зовнішній політиці України : дис.... канд. політ. наук: 23.00.04. "Політичні проблеми міжнародних систем та глобального розвитку». URL: http://mydisser.com/ ru/catalog / view / 247 / 251/12428.html.

20. Ржевська H. Стратегічне партнерство Україна-США: становлення та прогноз. URL: http://ipiend.gov.ua/ wp-content/uploads /2018/08/rzhevska_ strategichne.pdf.

21. Герасимчук В.Г. Стратегічне партнерство: принципи, інструментарій, ефекmuвність. URL: http://economy.kpi.ua/ files / files/10_kpi_2014.doc. 